The Structure of

Spherical Buildings 



\section{The Structure of Spherical Buildings}

Richard M. Weiss

PRINCETON UNIVERSITY PRESS

PRINCETON AND OXFORD 
Copyright (C) 2003 by Princeton University Press

Published by Princeton University Press,

41 William Street, Princeton, New Jersey 08540

In the United Kingdom: Princeton University Press,

3 Market Place, Woodstock, Oxfordshire OX20 1SY

All rights reserved

\section{Library of Congress Cataloguing-in-Publication Data}

Weiss, Richard M. (Richard Mark), 1946-

The structure of spherical buildings / by Richard M. Weiss.

p. $\mathrm{cm}$.

Includes bibliographical references and index.

ISBN 0-691-1 1733-0 (acid-free paper)

1. Buildings (Group theory). I. Title.

QA179.W45 2004

$512^{\prime} .2-\mathrm{dc} 21 \quad 2003050674$

British Library Cataloguing-in-Publication Data is available

This book has been composed in Times and LucidaSans

Typeset by $\mathrm{T}_{\&} \mathrm{~T}$ Productions Ltd, London

Printed on acid-free paper $\odot$

www.pupress.princeton.edu

Printed in the United States of America

$\begin{array}{llllllllll}10 & 9 & 8 & 7 & 6 & 5 & 4 & 3 & 2 & 1\end{array}$ 
I am not interested in constructing a building, so much as in having a perspicuous view of the foundations of possible buildings.

Ludwig Wittgenstein, Culture and Value 
